\title{
KONSEP TASHAWWUR AI-HAYAH DAN GHAYAH AL-HAYAH DALAM BEKERJA PERSPEKTIF AL-QUR'AN
}

\author{
Zaki Mubarak \\ Fakultas Ushuluddin dan Studi Agama UIN Sulthan Thaha Saifuddin Jambi, Indonesia \\ zakimubarak@uinjambi.ac.id
}

\begin{abstract}
Abstrak:
Tulisan ini mengkaji tentang konsep bekerja yang di era modernisasi saat ini tengah mengalami distansi dari tujuannya. Kebutuhan hidup yang semakin menghimpit dan lapangan pekerjaan yang semakin sempit membuat manusia menghalalkan segala cara dalam memperoleh harta. Sehingga konsep bekerja manusia saat ini menjadi penting untuk dikaji berlandaskan pedoman umat Islam yakni al-Qur'an. Dalam menganilisis permasalahan penulis menggunakan metode tafisr maudhu'i (tafsir tematik). Hasil dari tulisan ini memperlihatkan bahwa al-Qur'an telah memberikan pedoman bagi manusia dalam bekerja yang dapat dirangkum dalam konsep tashawwur al-hayah dan ghayah al-hayah. Dalam bingkai tashawwur al-hayah (tujuan hidup di dunia) bekerja merupakan tanggung jawab dalam memenuhi kebutuhan pribadi, keluarga, dan masyarakat yang harus dimulai dengan niat, tempat, dan cara yang baik. Sedangkan dalam bingkai ghayah al-hayah (tujuan hidup manusia), bekerja merupakan realisasi dari fungsi ibadullah dari hasil bekerja yang didistribusikan kepada sail dan mahrum, baik yang bersifat ijbari maupun ikhtiyari.
\end{abstract}

Kata Kunci: Bekerja, Tashawwur, Ghayah, al-Hayah.

\begin{abstract}
:
This paper examines the concept of work which in the modernization era is currently experiencing a distortion of its objectives. The need for life that is increasingly squeezed and increasingly narrow employment opportunities make people justify any means of obtaining property. So that the concept of human work is now important to be studied based on the guidelines of the Muslims, namely the Qur'an. In analyzing the problem, the writer uses the method of tafsir maudhu'i (thematic interpretation). The results of this paper show that al-Qur'an has provided guidelines for humans in their work which can be summarized in the concepts of tashawwur al-hayah and ghayah al-hayah. In the framework of tashawwur al-hayah (the purpose of life in the world) work is a responsibility in meeting personal, family, and community needs that must begin with good intentions, places, and ways. While in the frame of ghayah al-hayah (the purpose of human life), work is a realization of the function of ibadullah from the work that is distributed to sail and mahrum, both ijbari and ikhtiyari.
\end{abstract}

Keywords: Work, Tashawwur, Ghayah, al-Hayah. 
Vol. 2 No. 2 (Desember 2019)

\section{PENDAHULUAN}

Allah SWT menciptakan manusia untuk menjadi khalifah di muka bumi (QS.Al-Baqarah:30). Khalifah yang memikul amanah dan mandat untuk mengelola dan memakmurkan bumi (QS.Hud:61). Mandat ini mengandung makna tanggung jawab untuk menjalani kehidupan di dunia (tashawwur alhayah) baik terhadap diri pribadi, tanggung jawab terhadap keluarga, serta tanggung jawab terhadap sosial masyarakat sesama manusia dengan sebaikbaiknya sesuai dengan apa yang telah diperintahkan dan dilarang oleh Allah SWT. Konstruk kehidupan dalam merealisasikan fungsi ibadullah (hamba Allah) menuju kehidupan kekal abadi sebagai tujuan hidup manusia yakni akhirat (ghayah al-hayah).

Dalam menjalani konstruk kehidupan di alam dunia (tashawwur alhayah), secara naluriah manusia memerlukan kebutuhan-kebutuhan untuk melangsungkan hidup (survive to life), baik kebutuhan pokok (primary needs) dan kebutuhan tambahan (secondary needs) yang secara potensial telah Allah SWT sediakan diseluruh penjuru bumi, baik di darat maupun di laut yang harus direspon oleh manusia melalui usaha atau bekerja (QS. Al-Isra:70). Ibnu khaldun mengatakan bahwa bekerja merupakan perwujudan peranan manusia dalam mengelola dan memakmurkan bumi.(Khaldun, 1993, hlm. 301)

Berusaha atau bekerja, menggali dan mencari rezeki dalam kehidupan, baik menjadi petani, pengusaha, tukang kayu, penggembala, pemimpin negara, bahkan tokoh agama, dan jenis pekerjaan lainnya, adalah sebagai bentuk dari implementasi kerja yang bertujuan memenuhi kewajiban dan tanggung jawab terhadap diri pribadi (ifrad), keluarga (aqriba'), dan kepentingan sosial (ummah) (QS.39:39). Secara pribadi manusia wajib bekerja untuk keperluan sehari-hari sepeti makan, minum, pakaian, dan tempat tinggal, atau setidaknya untuk bertahan hidup (survive). Secara keluarga manusia wajib bekerja untuk memenuhu tanggung jawab memberikan nafkah bagi istri dan anak-anaknya. Sedangkan secara sosial masyarakat manusia wajib bekerja sebagai identitas diri dan membantu sesama saudara seiman, sebangsa, dan bahkan sesama manusia.(Madjid, 2003, hlm. 146)

Namun ironinya, di era modernisasi yang sarat dengan materi saat ini manusia untuk mempertahankan koeksistensi kehidupannya, banyak melahirkan syahwat maaliyah, yang memalingkan perhatiannya untuk lebih mencari harta, bertujuan untuk meraih prestise dan status sosial semata. Manusia bekerja sekuat tenaga, siang dan malam memabnting tulang hingga lupa waktu dan aturan. Menghalalkan segala cara untuk mendapatkan harta 
Vol. 2 No. 2 (Desember 2019)

sebanyak-banyaknya. Kehidupan duniawi menjadi faktor dominan dan bahkan prioritas utama dalam kehidupan.(Wach, 1958, hlm. 129)

Di sisi lain, terdapat pula sebagian manusia yang malas untuk bekerja dan terjebak pada ibadah ritual saja. Golongan ini cenderung meninggalkan perkara duniawiyah, dan memusatkan seluruh waktu siang malamnya hanya untuk beribadah, sehingga sepanjang hidupnya dihabiskan untuk beribadah dengan cara mengasingkan diri (uzlah). Padahal dalam pelaksanaan ibadah membutuhkan sokongan dan dukungan harta. Sebagai contoh yang lpaling mudah adalah kebutuhan materi untuk membeli pakain dalam menutup aurat, hingga memberi sedekah, menyantuni anak yatim, memberi makan fakir dan miskin, hingga menunaikan ibadah haji yang membutuhkan biaya yang besar.

Dalam Islam, esensi bekerja adalah tugas mulia manusia dalam menjalani kehidupan dunia (Tashawwur Al-Hayah) yang mengatur tujuan, manfaat, dan sasaran bekerja. Dalam Alqur'an Allah mengisyaratkan agar manusia seimbang dalam menjalani hidup (equal of life) di. Agar tidak melupakan akhirat ketika menjalani kehidupan di dunia, dan sebaliknya untuk meninggalkan kehidupan dunia dengan beribadah sebanyakbanyaknya agar mendapat kebahagiaan di kehidupan akhirat (QS.AlQashash:77). Oleh karena itu, tulisan ini akan mengkaji konsep bekerja dalam pespektif al-Qur'an dengan konsepkeseimbangan yang dikenal dengan tashawwur al-hayah dan ghayat al-hayah. Konsep ini memuat ajaran tentang keniscayaan bekerja, sasaran bekerja, dan tujuan bekerja.

\section{PEMBAHASAN}

\section{Tashawwur Al-Hayah; Bekerja adalah Keniscayaan}

Secara etimologi Tashawwur Al-Hayah berasal dari kata tashawwur yang artinya bingkai dan al-hayah yang artinya kehidupan.(Atabik, 1999, hlm. 498, 808) Sedangkan secara terminology tashawwur al-hayah menyangkut dengan upaya manusia untuk memenuhi tugasnya sebagai khalifah fi al-ardi yang harus dipenuhi dengan kebutuhan sandang pangan dan papan. Adalah sunnatullah, bahwa demi keberlansungan hidupnya, manusia membutuhkan kebutuhan-kebutuhan hidup yang azazi berupa makanan dan minuman, pakaian, dan tempat tinggal yang layak (primary needs), serta kebutuhan-kebutuhan tambahan (secondary needs) yang menunjang hidup dan kehidupan manusia di dunia (tashawwur al-hayah). Sunnatullah ini menunjukkan keniscayaan bekerja dalam konstruk kehidupan dunia (tashawwur al-hayah) yang tidak bisa dipungkiri, karena materi dibutuhkan untuk memenuhi kebutuhan baik secara individu maupun 
Vol. 2 No. 2 (Desember 2019)

sosial, biologis maupun fisiologis. Secara biologis, manusia harus mengupayakan materi untuk membangkitkan gairah hidup secara kemakhlukan dam secara fisiologis, manusia harus mencari nilai yang ada di balik materi yang ditangkap oleh visual inderanya.

Dalam pandangan para fuqaha' (ulama fiqh), kerja dikategorikan sebagai kewajiban individu yang di atasnya ditunaikan kewajiban kolektif. Hal ini karena kebutuhan kolektif tidak akan terpenuhi sebelum kebutuhan individu tercukupi. (al-Makhzanji, 1998, hlm. 27) Allah SWT memerintahkan hambanya dalam mencari karunia dan rezeki yang telah disediakan di seluruh penjuru bumi dalam bentuk profesi masing-masing sesuai dengan skill (kemampuan) dan kesanggupan masing-masing individu untuk mencari harta dalam bentuk materi yang digunakan untuk bertahan hidup dan beribadah kepada-Nya.

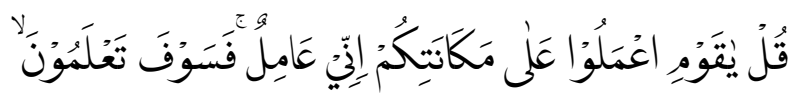

Artinya: Katakanlah: Hai kaumku, Bekerjalah sesuai dengan keadaanmu, Sesungguhnya aku akan bekerja (pula), Maka kelak kamu akan mengetahui. (QS. Al-Zumar:39)

Manusia diperintahkan untuk mencari rezeki dalam berbagai bentuk pekerjaan yang halal lagi baik, untuk mendapatkan materi dalam mencukupi kebutuhan keluarga (sa'yan ala iyalihi) yang merupakan kewajiban fardlu ain bagi kepala keluarga yang harus dilakukannya sebagai senuah kewajiban yang tidak dapat diwakilkan, dan menunaikannya termasuk kategori jihad di jalan Allah SWT. Rasulullah SAW bersabda dalam sebuah Haditsnya yang berbunyi:

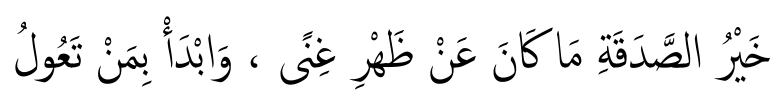

Artinya: Sedekah yang terbaik adalah yang dikeluarkan selebih keperluan, dan mulailah dari orang yang kamu tanggung. (HR. Bukhari)

Islam melarang umatnya untuk berlebihan dalam membatasi gerak hidup (tafrith), sehingga mengharamkan kenikmatan-kenikmatan yang Allah halalkan. Kehidupan manusia mesti diisi dengan tanggung jawab sebagai khalifah fi al-ard, mengelola dan memakmurkan alam. Kehidupan dunia tidak hanya sebatas tempat singgah sementara yang diartikan dalam makna sempit, sehingga banyak yang memahami hanya sebagai tempat singgah yang tidak perlu diisi dengan tidak mengambil bagian yang pada fitrahnya telah 
Vol. 2 No. 2 (Desember 2019)

Allah sediakan bagi manusia sebagai sarana dalam untuk meraih kehidupan abadi di akhirat.

Melaksanakan ibadah-ibadah memang merupakan kewajiban yang telah Allah SWT perintahkan, namun ibada-ibadah tersebut tidak menyebabkan manusia lupa akan tanggung jawabnya di kehidupan dunia. Bekerja dan iabadah merupakan dua hal yang tidak terpisahkan. Allah SWT menggadengkan ibadah dan bekerja dalam satu ayat yang digandengkan secara khsus. Oleh karena itu, meninggalkan bagian duniawi dengan alasan untuk fokus beribadah adalah sebuah kekeliruan, karena "Sesungguhnya matamu memilki hak atasmu, tubuhmu memiliki hak atasmu dan keluargamu juga memiliki hak atasmu. Maka shalatlah dan tidurlah.dan puasalah lalu berbukalah." (HR Bukhari).

Kemudian, Islam juga melarang umatnya terlalu longgar (ifrath) dalam mengisi kehidupan di dunia. Sikap menghambakan diri kepada dunia sehingga dunia adalah tujuan utama. Akhirnya menyebabkan seakan-akan semua hukum adalah halal sehingga menghalalkan segala cara (al ghayah tubarriru al washilah) dalam mencari harta, juga merupakan sebuah kekeliruan yang berbanding terbalik dengan anjuran dan cita-cita Islam. Hal ini ditegaskan dalam firman Allah SWT :

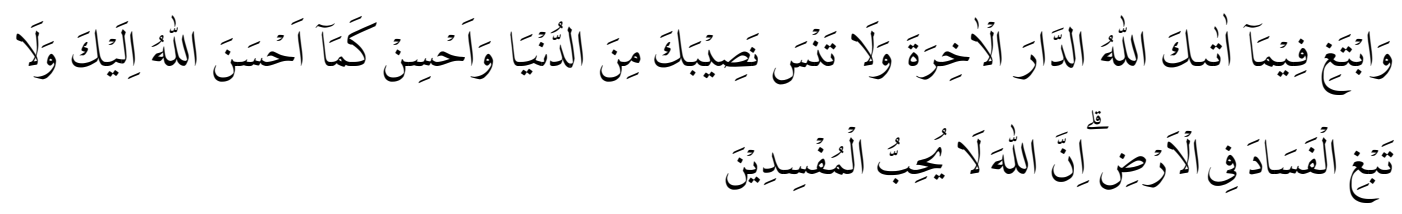

Artinya: dan carilah pada apa yang telah dianugerahkan Allah kepadamu (kebahagiaan) negeri akhirat, dan janganlah kamu melupakan bahagianmu dari (kenikmatan) duniawi dan berbuat baiklah (kepada orang lain) sebagaimana Allah telah berbuat baik, kepadamu, dan janganlah kamu berbuat kerusakan di (muka) bumi. Sesungguhnya Allah tidak menyukai orang-orang yang berbuat kerusakan. (QS. al-Qashash: 77).

Ahmad Mustafa Al-Maraghy di dalam tafsirnya Al-Maraghy menjelaskan, bahwa di dalam ayat ini Allah SWT melarang manusia untuk melupakan bagian dari kenikmatan duniawi yang diperkenankan oleh Allah berupa makanan, minuman, pakaian, perkawinan, dan perumahan. Asalkan saja tidak melampaui batas.(Al-Maraghy, 2006, hlm. 182) Sayyid Qutbh mendefinisikan karunia Allah kepada manusia di dunia diantaranya adalah kesehatan, kekuatan, keturunan dan kesenangan material. Nikmat-nikmat tersebut hendaknya digunakan oleh manusia untuk mencari kebahagiaan 
Vol. 2 No. 2 (Desember 2019)

akhirat. Dengan demikian, manusia tidak dilarang memiliki harta, tetapi dilarang untuk terlalu sibuk mengurusi harta. (Quthb, 1992, hlm. 287)

Rasulullah SAW bersabda dalam sebuah Hadits yang diriwayatkan Ibnu Asakir yang berbunyi:

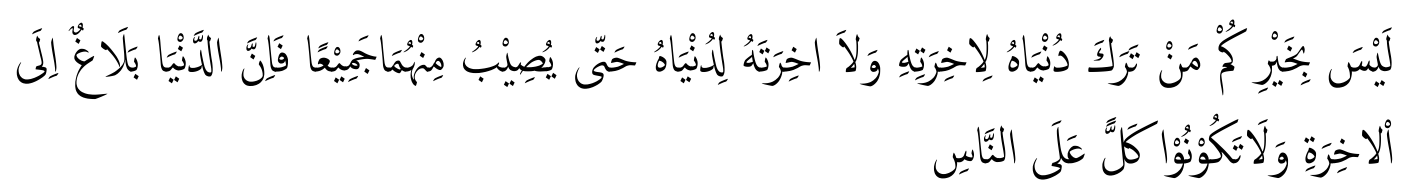

Artinya: Bukanlah yang terbaik diantara kamu orang yang meninggalkan urusan dunianya karena (mengejar) urusan akhiratnya, dan bukan pula (orang yang terbaik) oarang yang meninggalkan akhiratnya karena mengejar urusan dunianya, sehingga ia memperoleh kedua-duanya, karena dunia itu adalah (perantara) yang menyampaikan ke akhirat, dan janganlah kamu menjadi beban orang lain. (HR. Ibu 'Asakir).

Karenanya, Islam tidak menginginkan manusia hanya melakukan ibadah yang bersifat vertikal (hablum minallah), tapi juga mengajarkan untuk memperhatikan urusan kebutuhan duniawinya (sandang, pangan, papan) dengan keseimbangan hidup yang tidak mengabaikan tuntutan aspek materi, dan tidak pula menghambakan diri dengan terjerumus pada kemilau dunia. Karena antara pemenuhan kehidupan di dunia dan mempersiapkan kehidupan di akhirat kelak, keduanya saling menopang.

\section{Al-Qur'an dan Bekerja dalam Tashawwur Al-Hayah}

Bekerja, adalah salah satu identitas manusia dalam memanusiakan dirinya, karena kesadaran bekerja akan melahirkan suatu kemajuan (improvement) untuk meraih nilai yang lebih bermakna dalam kehidupan dunia. Bekerja merupakan aktivitas dinamis yang dapat mengarahkan manusia pada perubahan-perubahan positif dalam kehidupannya. (Tasmara, 1995, hlm. 4) Dalam al-Qur'an, kata Bekerja dalam bentuk perintah (fi'il 'amar): "i'maluu”, di dalam al-Qur'an tidak kurang disebut sebanyak 9 kali dalam setiap sebaran ayatnya. (Baqy, 1942, hlm. 618)

Weber, sebagaimana yang dikutip oleh oleh Nanat Fatah Natsir dalam bukunya Etos Kerja Kewirausahaan Muslim, menyatakan bahwa bekerja adalah merupakan tugas suci manusia dalam kehidupannya di dunia. (Natsir, 1999, hlm. 11) Manusia yang enggan bekerja atau tidak mau mendayagunakan seluruh potensi dirinya untuk memanifestasikan keimanan dalam bentuk amal kreatif, sesungguhnya telah menentang fitrahnya sendiri dan menurunkan derajatnya sebagai manusia. 
Vol. 2 No. 2 (Desember 2019)

Begitu pentingnya kewajiban bekerja dalam al-Qur'an, Allah SWT memerintahkan untuk bertebaran mencari rezeki untuk memenuhi kebutuhan hidup setelah selesainya ibadah. Firman Allah SWT:

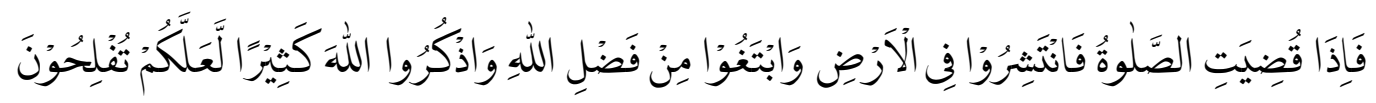

Artinya : Apabila telah ditunaikan shalat, Maka bertebaranlah kamu di muka bumi; dan carilah karunia Allah dan ingatlah Allah banyak-banyak supaya kamu beruntung. (QS. Al-Jumu'ah:10).

M. Quraish Shihab dalam tafsirnya Al-Mishbah menjelaskan ayat ini dengan apabila seseorang telah melakukan shalat, maka bertebaranlah untuk berbagai kepentingan. Carilah karunia Allah dan berzikirlah kepada-Nya banyak-banyak, dalam hati maupun dengan ucapan. Mudah-mudahan kalian memperoleh keberuntungan dunia dan akhirat. (Shihab, 2012, hlm. 1024)

Manusia yang giat bekerja akan membentengi kehidupannya dari kesusahan dan kemelaratan. Sebab bekerja merupakan sarana memelihara iman yang akan memantapkan keyakinan hati bahwa apa saja yang dikerjakan di dunia ini akan dibalas oleh Allah SWT. Islam mengajarkan prinsip bekerja dalam mempersiapkan kebutuhan di dunia seakan-akan bahwa manusia itu akan hidup selama-lamanya. Prinsip ini mengandung makna manusia harus giat, ulet, dan bekerja keras dalam meraih rizki dengan tidak bermalas-malasan dan cepar merasa puas. Rasulullah SAW, di dalam Haditsnya mengisyaratkan urgensi bekerja dengan perintah sebagaimana yang diriwayatkan oleh Imam Baihaki yang berbunyi:

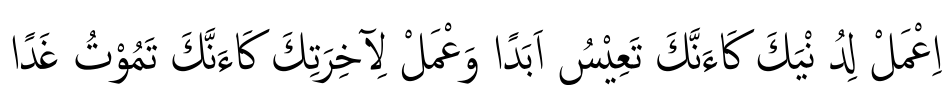

Artinya: Bekerjalah untuk duniamu seakan akan kamu akan hidup selamnya dan bekerjalah untuk akhiratmu seakan akan kamu akan mati besok pagi. (HR. Baihaqi)

Giat bekerja karena seolah-olah akan hidup selamanya merupakan motivasi agar menjadi manusia akan menjadi kuat. Kuat dalam fisik tubuh karena memiliki pangan yang cukup, kuat dalam ekonomi karena mempunyai harta, kuat dalam posisi sosial karena tidak dipandang miskin dan rendah. Sabda Rasulullah SAW: 


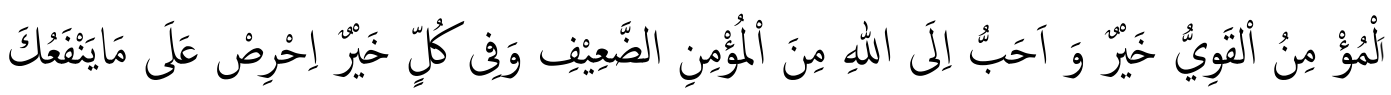

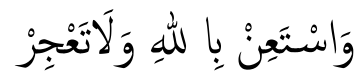

Artinya: Mukmin yang kuat lebih baik dan lebih dicintai oleh allah dari pada mukmin yang lemah, sedangkan pada masing masing ada kebaikannya. Bersemangatlah kamu untuk mencapai sesuatu yang bermanfaat bagimu. Mohonlah pertolongan kepada allah dan janganlah kamu merasa tidak berdaya. (HR. Muslim).

Thohir Luth menyatakan bahwa dalam diri tiap seorang Muslim harus memiliki sikap kerja keras (al-jiddu fi al-'amal). Bekerja keras menjadi syarat mutlak yang harus ada dalam jiwa tiap Muslim, sebagaimana agama membenci kemalasan. Kemudian yang harus dimiliki oleh jiwa tiap Muslim adalah al-himmah al-'aliyah, yakni cita-cita yang tinggi. Karena salah satu perbedaan mendasar dan esensial dari manusia dan binatang adalah ada dan tidaknya cita-cita atau idealisme yang terpatri dalam jiwa, dan manusia tanpa cita-cita bagaikan seonggok daging dan tulang tanpa energi. (Luth, 2011, hlm. 41)

Rasulullah SAW menjanjikan kemuliaan bagi seseorang yang bekerja untuk memenuhi kebutuhan hidupnya. Sebagaimana Hadits yang diiwayatkan oleh Zubair bin Awwam yang berbunyi:

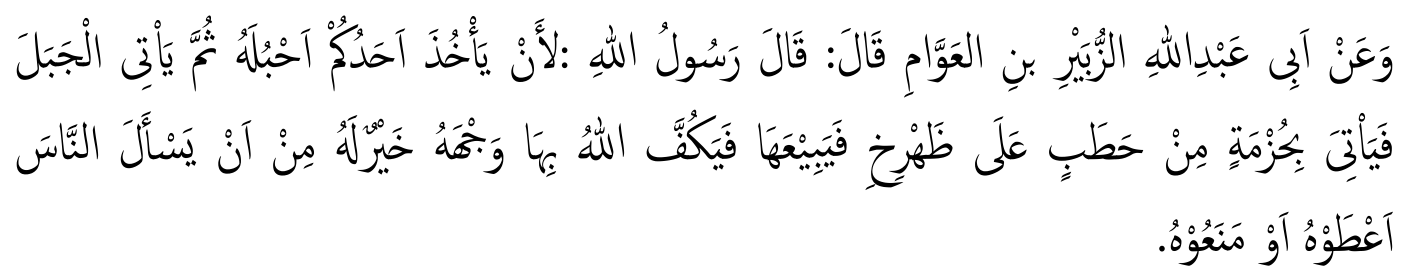

Artinya: Dari Abi Abdillah (Zubair) bin Awwam Radhiyallahu 'anhu, ia berkata: Rasulullah bersabda: "Sesungguhnya, seorang di antara kalian membawa talitalinya dan pergi ke bukit untuk mencari kayu bakar yang diletakkan di punggungnya untuk dijual sehingga ia bisa menutup kebutuhannya, adalah lebih baik daripada meminta-minta kepada orang lain, baik mereka memberi atau tidak. (HR Bukhari, No. 1471)

Penghargaan Islam terhadap kerja bakan sampai kiamat sudah dekat (QS.6:132, QS.67:2), karena bekerja menjadi harga diri (kehormatan) seseorang berikut derajatnya di dunia dan di akhirat yang berbanding lurus dengan instrumen amaliahnya di dunia. (Suma, 2013, hlm. 53) Rasulullah SAW bersabda: 


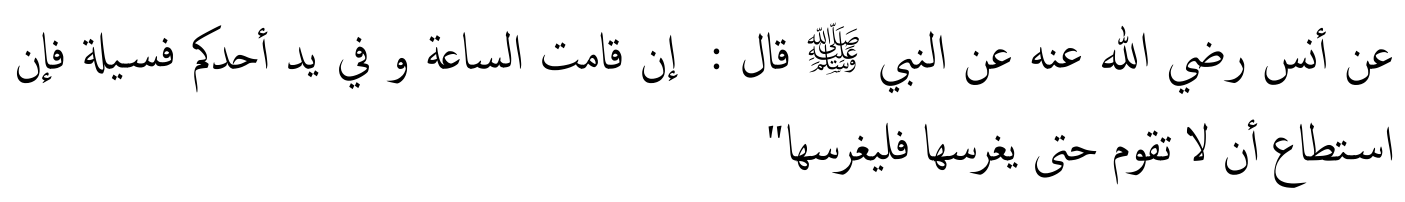

Artinya: Dari Anas RA, dari Rasulullah saw, beliau bersabda, Jika hari kiamat terjadi, sedang di tanganmu terdapat bibit tanaman, jika ia bisa duduk hingga dapat menanamnya, maka tanamlah. (HR. Bukhari dan Muslim).

Dengan demikian, secara hakiki bekerja bagi seorang muslim merupakan bukti pengabdian dan rasa syukurnya untuk mengolah dan memenuhi panggilan Ilahi agar mampu menjadi yang terbaik karena mereka sadar bahwa bumi diciptakan sebagai ujian bagi mereka yang usaha terbaik. Bekerja dengan energi batin yang terus menyala dan mendorong setiap langkah kehidupannya dalam koridor jalan yang lurus. (Tasmara, 2002, hlm. 26)

\section{Manfaat dan Sasaran Kerja bagi Ghayah Al-hayah}

Bekerja dalam Islam tidaklah dilandasi oleh tujuan-tujuan yang bersifat duniawi belaka, tidak hanya sekedar pemenuhan keperluan untuk bertahan hidup, tetapi merupakan sebuah tugas suci dalam mengabdi kepada Allah. Bekerja akan memberikan hasil yang memungkinkan manusia dapat makan, berpakaian, tinggal di sebuah rumah, memberi nafkah keluarga, dan menjalankan bentuk-bentuk ibadah lainnya secara baik. Materi dari hasil bekerja, selain digunakan untuk memenuhi kebutuhan sendiri, keluarga termasuk istri, anak-anak dan orang tua merupakan manfaat dan sasaran kerja secara internal yang tampak oleh kewajiban kasat mata. Namun secara eksternal, Islam menghargai semua itu sebagai sedekah, ibadah, dan amal saleh sebagai bekal untuk tujuan hidup sebenarnya yakni akhirat, yang dalam tulisan ini disebut dengan Ghayat al-hayah. Ghayat berarti tujuan dan alhayah yang artinya kehidupan. (Atabik, 1999, hlm. 1341)

Bekerja untuk memenuhi kebutuhan keluarga yang menjadi tanggungannya adalah kewajian bagi seorang muslim, dan harta yang dinafkahkan tersebut akan menjadi suatu ibadah yang akan mendapatkan ganjaran dari Allah SWT. Rasulullah SAW bersabda:

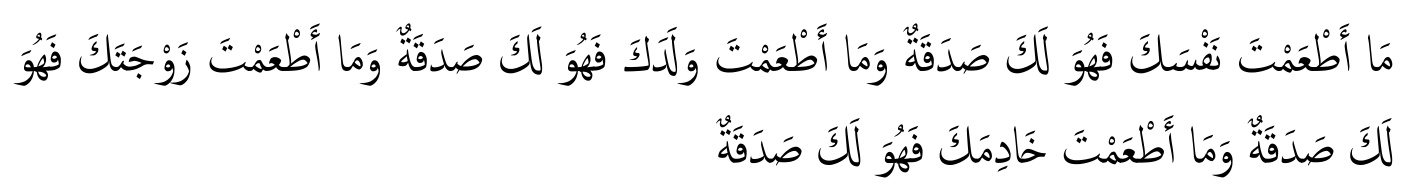

Artinya: Harta yang dikeluarkan sebagai makanan untukmu dinilai sebagai sedekah untukmu. Begitu pula makanan yang engkau beri pada anakmu, itu 
Vol. 2 No. 2 (Desember 2019)

pun dinilai sedekah. Begitu juga makanan yang engkau beri pada istrimu, itu pun bernilai sedekah untukmu. Juga makanan yang engkau beri pada pembantumu, itu juga termasuk sedekah. (HR. Ahmad.)

Hadits di atas dengan sangat jelas memberikan penjelasan bahwa setiap harta yang dikeluarkan untuk dinafkahkan kepada keluarga, dan kaum kerabat, kepada pembantu, semuanya akan dinilai sebagai sebuah sedekah yang akan diberi ganjaran oleh Allah SWT di akhirat nanti. Namun demikian, sebaliknya daripada itu, orang-orang yang mengabaikan dan menelantarkan tanggung jawab keluarga merupakan sikap kufur denagn anugerah potensial berupa SDA dan SDM yang telah diberikan oleh Allah SWT. sabda Rasulullah SAW yang berbunyi:

$$
\text { قال رسول الله : كفى بالمره إثماً أن يضيع من يقوت" رواه أحمد وأبو داود وصححه الحالج وأقره }
$$

Artinya: Rasulullah saw bersabda, Cukuplah seseorang dianggap berdosa jika ia menelantarkan orang-orang yang menjadi tanggung jawabnya. (HR. Ahmad, Abu Daud dan al-Hakim).

Menginfaqkan harta bagi keluarga adalah hal yang harus diutamakan, baru kemudian pada lingkungan terdekat, dan kemudian lingkungan yang lebih luas. Pekerjaan yang dilakukan seseorang bisa menjadi sebuah amal jariyah baginya, karena tidaklah seorang mukmin menanam tanaman, atau menabur benih, lalu burung atau manusia atau hewan pun makan darinya kecuali pasti bernilai sedekah baginya. Rasulullah SAW bersabda:

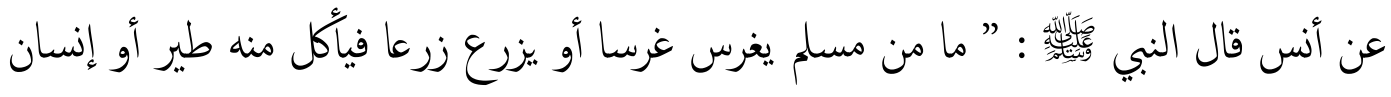

$$
\begin{aligned}
& \text { أو بهيمة إلا كان له به صدقة “ }
\end{aligned}
$$

Artinya: Dari Anas, Rasulullah saw bersabda, Tidaklah seorang mukmin menanam tanaman, atau menabur benih, lalu burung atau manusia atau hewan pun makan darinya kecuali pasti bernilai sedekah baginya. (HR Bukhari)

Dalam syari'at Islam, harta mempunyai peran penting untuk dapat menjalankan ketentuan-ketentuannya, sasaran dan manfaat kerja berpengaruh terhadap ghayat al-hayah. Karena Ibadah yang sepintas bersifat 
fisik, bukan berarti tidak membutuhkan materi. Orang dapat shalat dengan tenang, jika seluruh tanggungannya telah terpenuhi, baik terhadap dirinya maupun orang lain yang menjadi tanggungannya. Terlebih ibadah yang secara lahir memang membutuhkan materi, secara mutlak manusia harus bekerja untuk mendapatkan kekayaan. ('Abduh \& Ismail, t.t., hlm. 39) Sebagai contoh paling dominan adalah dua rukun Islam yang mensyaratkan kemampuan ekonomi yang cukup, yakni kewajiban zakat dan ibadah haji. (Alkindi, 1997, hlm. 27)

Kemudian aktivitas "solidaritas sosial" yang merupakan perwujudan dari kondisi manusia yang satu dengan yang lainnya saling membutuhkan, juga menuntut harta untuk dapat merealisasikannya. Adanya orang miskin dan fakir sebagai peluang bagi orang yang memiliki harta lebih untuk menafkahkan atau menyedekahkannya. Karena itu, tidak heran ketika alQur'an dengan ayat-ayatnya menyerukan kaum muzakki (orang kaya yang kelebihan harta) untuk peduli terhadap kaum mustahik (orang miskin yang kekurangan).

Al-Qur'an memberikan kecaman terhadap manusia yang menumpuk harta dan mengharamkan kekayaan itu beredar hanya pada kaum agniya' (orang kaya) saja. Dalam harta yang dimiliki oleh seseorang yang berkecukupan, sesungguhnya terdapat bagian bagi orang-orang yang meminta (sail) dan orang-orang yang tidak meminta (mahrum). (QS.51:19). Lebih tegas, Allah bahkan menyebut orang yang rajin beribadah tetapi mengabaikan nasib kaum miskin dan yatim sebagai pendusta-pendusta agama (QS.107:1-3). Dukungan sikap prihatin kaum agniya' (kaya) dapat direalisasikan dalam bentuk pemberian bantuan berupa zakat, infaq, dan sadaqah agar dapat meminimalisir kesenjangan status ekonomi yang telah berkembang dalam masyarakat. Terutama bagi kaum miskin yang betul-betul tidak mampu secara ekonomi akibat dari persaingan hidup yang terlalu sulit.

Namun demikian, bukan berarti Al-Qur'an mengizinkan adanya para pengemis dan peminta-minta yang menyebabkan manusia malas dalam bekerja. Sikap meminta-minta akan merendahkan martabat nilai kemanusiaan (al-Baqarah:273). Al-Qur'an menginginkan agar manusia menghargai potensi yang dianugerahkan Tuhan, baik berupa alam maupun yang ada pada diri manusia. Penghambaan manusia kepada sesamanya atau kepada alam secara umum, karena manusia tidak pernah mengenali potensi yang ada pada dirinya. Ketika manusia mengenali potensinya, Tuhan akan memberikan jaminan kecukupan kebutuhannya (Ibrahin:34).

Dengan demikian, dapat dipahami bahwa bekerja secara input adalah proses melahirkan produktivitas bagi kemanfaatan hidup diri pribadi, 
Vol. 2 No. 2 (Desember 2019)

keluarga, dan masyarakat sosial secara umum. Selain itu secara output melahirkan distribusi yang akan dibalas dengan ganjaran pahala. Harta kekayaan dari hasil kerja bukan hanya berdimensi horizontal antara manusia dengan Allah SWT, tetapi juga berdimensi vertikal antar sesama manusia, baik distribusi harta yang bersipat ijbari maupun ikhtiyari.

\section{Nilai Ibadah Kerja dalam Ghayah A-Hayah}

Bekerja adalah aktifitas yang memiliki nilai tambah sebagai ibadah kepada Allah SWT, karena amal usaha dan aktifitas ini akan memungkinkan masyarakat melaksanakan risalah islam, melaksanakan da'wahnya, menjaga dirinya dan membantunya dalam rangka merealisasikan tujuan tujuannya yang lebih besar. (Qardhawi, 2004, hlm. 151) Berhasil dan gagal, tinggi dan rendahnya kualitas hidup seseorang ditentukan oleh amal dan kerjanya (QS.18:7). Lulus atau tidaknya manusia dalam menghadapi ujian hidup di dunia ini dapat dilihat dari amal atau kerja yang telah dilakukan. Apalagi manusia diberikan tugas sebagai khalifah yang bertugas sebagai pemakmur bumi.

Konsep keimanan, sejatinya berkaitan erat dengan kerja (amal), karena iman dan amal shaleh merupakan dua aktivitas yang tidak dapat dipisahkan satu sama lain. Al-Qur'an menggandengkan lafadz amanu dengan lafadz amilu as-solihat, yang diidentifikasikan dengan makna aktivitas kerja sebanyak 25 kali dalam sebaran ayat-ayatnya. (Harahap, 1997, hlm. 74) Iman bukanlah suatu hal yang abstrak, melainkan sesuatu yang empirik, iman bukanlah sekedar ketetapan hati ataupun ucapan lisan, tetapi iman harus diaktualisasikan sebagai sebuah aktivitas kerja.

Aktivitas kerja sebagai sebuah fitrah yang jika dilakukan manusia akan menjadi ekuivalen dengan pernyataan syukurnya kepada Sang Pencipta, Allah SWT. Konsekuensi logisnya adalah bahwa siapapun yang tidak bekerja, hidupnya tidaklah produktif dan tidak pula bermakna. (Madjid, 2003, hlm. 412) Tanpa bekerja, manusia tidak akan bias untuk mengabdi kepada Allah, materi dibutuhkan untuk melaksanakan ibadah kepada Allah SWT dalam bentuk ibadah ijbari (paksaan/ sudah ditetapkan) dan ikhtiyari (pilihan). Ibadah ijabari merupakan pendistribusian harta yang langsung diinstruksikan oleh perintah Allah SWT berupa paksaan dengan jumlah dan peruntukannya seperti waris dan zakat. Sedangkan ibadah ikhtiyari merupakan pendistribusian harta pilihan berupa infaq, sedekah, wakaf, hibah, wasiat, dan hadiah.

Bekerja secara lahiriyah memang hanya sebagai kewajiban berupa materi untuk mencukupi kebutuhan hidup. Tetapi secara bathiniyah 
Vol. 2 No. 2 (Desember 2019)

mengandung nilai-nilai ibadah, berupa pendistribusian harta yang bersifat ijbari dan ikhtiyari dengan mengharapkan ridho dan balasan dari Allah SWT.

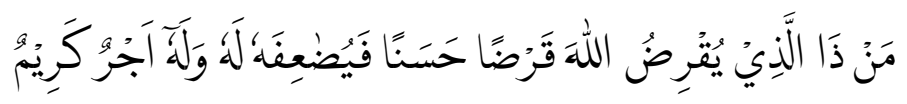

Artinya : Siapakah yang mau meminjamkan kepada Allah pinjaman yang baik, Maka Allah akan melipat-gandakan (balasan) pinjaman itu untuknya, dan Dia akan memperoleh pahala yang banyak. (QS. Al-Hadid:11)

Allah SWT menggandengkan orang yang bekerja dengan jihad memerangi orang-orang kafir (QS.73:20). Rasulullah shallallahu 'alaihi wa sallam bahkan menyebutkan bahwa aktifitas bekerja sebagai jihad di jalan Allah. "sesungguhnya Allah mencintai hamba-hambanya yang bekerja keras dan terampil. Barangsiapa bersusah payah mencari nafkah untuk keluarganya, maka dia serupa dengan seorang mujtahid di jalan Allah (HR. Ahmad).

Setiap pekerjaan yang dilakukan oleh manusia akan bernilai ibadah yang akan dilihat dan dinilai langsung dari Allah SWT dan Rasul-Nya. Firman Allah SWT :

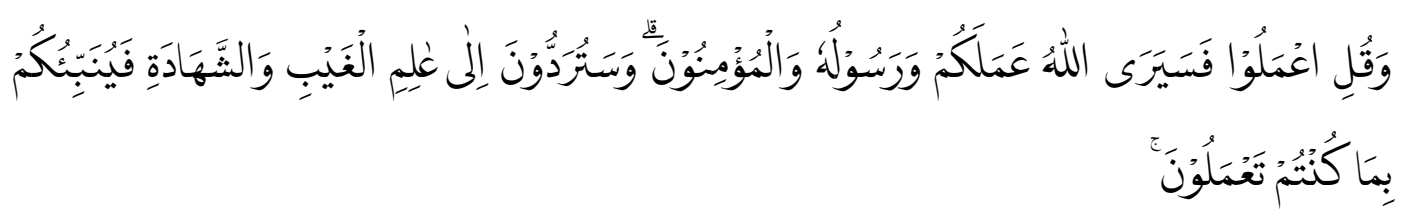

Artinya: dan Katakanlah: "Bekerjalah kamu, Maka Allah dan Rasul-Nya serta orang-orang mukmin akan melihat pekerjaanmu itu, dan kamu akan dikembalikan kepada (Allah) yang mengetahui akan yang ghaib dan yang nyata, lalu diberitakan-Nya kepada kamu apa yang telah kamu kerjakan. (QS. At-Taubah:105).

Dengan demikian, bekerja mesti di-bulit-in dengan pemahaman tashawwur al-hayah dan ghayat al-hayah agar bekerja dapat menjadi suatu identitas manusia yang memberikan kemuliaan, berasaskan manfaat, dan tentunya mendapatkan keberkahan, pahala, dan keridhaan Allah SWT (QS.48:29), mendapatkan keutamaan (kualitas dan hikmah), dengan tidak meninggalkan bahagiannya di dunia dan tidak pula terikat akan pesona dan kemilaunya, sehingga akan menggiring manusia kepada kehidupan yang hasanah fi al-dunya wa al-akhirat. 
Vol. 2 No. 2 (Desember 2019)

\section{PENUTUP}

Bekerja adalah fitrah dan kewajiban manusia sebagai khalifah fi alardi yang inheren dalam diri manusia untuk dapat merealisasikan konstruk tashawwur al-hayah dalam memenuhi kebutuhan untuk mempertahankan hidup (survive of life). Dengan bekerja manusia dapat merealisasikan tanggung jawab terhadap diri pribadi, keluarga, dan masyarakat.

Dalam realisasi kerja, al-Qur'an melarang manusia bermalas-malasan, mengecam manusia mendewakan harta, dan meninggalkan dunia dengan fokus beribadah, karena bekerja secara internal melakoni perjuangan kelangsungan hidup diri pribadi, tanggung jawab keluarga, dan sosial, sedangkan secara eksternal, harta yang didistribusikan kepada sail (pemintaminta) dan mahrum (tidak meminta), baik yang bersifat ijbari maupun ikhtiyari merupakan realisasi dari fungsi ibadullah yang merupakan dari konstruk ghayatul hayah.

Akhirnya, segala bentuk lakon yang dijalani oleh manusia di alam duniawi dan ukhrawi, pada hakikatnya adalah merupakan pencarian terhadap karunia dan ridho-Nya, sebagai ghayat dari penciptaan manusia yang termaktub dalam al-Qur'an; "Dan tidak aku ciptakan jin dan manusia kecuali untuk menyembah-Ku" (QS.51:56)

\section{REFERENSI}

'Abduh, I., \& Ismail. (t.t.). Al-'Amal fi al-Islam. Kairo: Dar al-Ma'arif.

al-Makhzanji, A.-S. A. (1998). Al-Zakah wa Tanmiyat al-Mujtama', Rabitah al'Alam al-Islami. Mekah: Rabitah al-'Alam al-Islami.

Alkindi, A.-S. (1997). Bekerja Sebagai Ibadah: Konsep Memberantas Kemiskinan, Kebodohan dan Keterbelakangan Umat, Solo: Aneka. Solo: Aneka.

Al-Maraghy, A. M. (2006). Tafsir Al-Maraghy. Beirut: Dar Al-Kutub Al-Ilmiyah. Atabik, A. (1999). Kamus Al-'Ashriy. Yogyakarta: Multi Karya Grafika.

Baqy, M. F. A. (1942). Al-Mu'jam al-Mufahras li al-Fadzh al-Qur'an al-Karim. Kairo: Dar al Kutub al-Mishriyyah.

Harahap, S. (1997). Islam Dinamis. Yogyakarta: Tiara Wacana Yogya.

Khaldun, I. (1993). Muqaddimah. Beirut: Dar Al-Kutub Al-Ilmiyah.

Luth, T. (2011). Antara Perut \& Etos Kerja dalam Perspektif Islam. Jakarta: Gema Insani Press.

Madjid, N. (2003). Islam Agama Kemanusiaan Membangun Tradisi dan Visi Baru Islam Indonesia. Jakarta: Paramadina.

Natsir, N. F. (1999). Etos Kerja Kewirausahaan Muslim. Bandung: Gunung Djati Press. 


\section{AT-TIBYAN}

Journal Of Qur'an and Hadis Studies

Vol. 2 No. 2 (Desember 2019)

Qardhawi, Y. (2004). Peran Nilai dan Moral dalam Perekonomian Islam. Jakarta: Rabbani Press.

Quthb, S. (1992). Tafsir Fi Zilal al-Qur'an (Vol. 1-VI). Kairo: Dar al-Syarq.

Shihab, M. Q. (2012). Tafsir Al-Mishbah: Pesan, Kesan, dan Keserasian AlQur'an. Jakarta: Lentera Hati.

Suma, M. A. (2013). Tafsir Ayat Ekonomi: Teks, Terjemah dan Tafsir. Jakarta: Amzah.

Tasmara, T. (1995). Etos Kerja Pribadi Muslim. Yogyakarta: Dana Bakti Wakaf.

Tasmara, T. (2002). Membudayakan Etos Kerja Islam. Jakarta: Gema Insani Press.

Wach, J. (1958). The Comparative Study of Religion. New York: Columbia University Press. 